\section{HAEMOGLOBIN-H DISEASE}

BY

J. P. BINGLE, B.M., M.R.C.P.

Medical Registrar, University College Hospital

E. R. HUEHNS, M.B., B.S.

Registrar, Department of Clinical Pathology, University College Hospital

AND

T. A. J. PRANKERD, M.D., M.R.C.P. First Assistant, Medical Unit, University College Hospital Medical School

Haemoglobin-H was first described in 1955 by Rigas, Koler, and Osgood. It differs from the other abnormal haemoglobins so far described in that its inheritance cannot be followed by electrophoresis in its heterozygous and homozygous forms. Usually in the haemoglobinopathies, adult haemoglobin $(\mathrm{HbA})$ and the abnormal haemoglobin are present in approximately equal quantities in the heterozygous state. In the homozygous state all or nearly all the haemoglobin present is of the abnormal type, the patient showing the features of the appropriate disease. In patients with haemoglobin-H disease the proportion of abnormal haemoglobin found varies from about 10 to $35 \%$. It is irregularly found in relatives of these patients. In both these respects it resembles the appearance of haemoglobin-F in thalassaemia. Clinically, haemoglobin-H disease is very similar to thalassaemia minor. Two cases of this rare disease are reported in which red-cell survival and marrow iron turnover have been studied.

\section{Methods}

1. Electrophoresis of haemoglobins was carried out on Whatman No. 1 and No. 31 extra thick chromatography papers, using a horizontal technique in barbiturate buffer pH 8.6, $M=0.05$. By this technique $\mathrm{HbA}_{2}$ can be separated from $\mathbf{H b A}$.

2. Red-cell survival time was estimated using the patient's own cells labelled with radioactive chromium $\left({ }^{51} \mathrm{Cr}\right)$ as described by Joske, McAlister, and Prankerd (1956).

3. The radioactive iron $\left({ }^{50} \mathrm{Fe}\right)$ turnover was studied by the technique described by Harris, McAlister, Prankerd, and Singh (1957).

4. The foetal haemoglobin (HbF) percentage was estimated by the method of Singer, Chernoff, and Singer (1951).

Identification of Haemoglobin-H.-The abnormal haemoglobin found in the cases described was identified by comparison with a sample kindly supplied by Dr. J. C. White and by moving boundary electrophoresis carried out by Dr. E. M. Shooter and Mr. R. E. Skinner.

\section{Case Reports}

Case 1.-A Greek Cypriot, aged 23 years, living in London, attended hospital complaining of occasional nocturnal epileptic fits. He had always been pale and had had a few attacks of jaundice. When he was 7 years old he was treated in a sanatorium for tuberculosis. On examination the only abnormal physical signs were pallor, slightly icteric conjunctivae, and a just palpable spleen. When he was first seen his reticulocyte count was $7.5 \%$. This gradually fell to normal at the time of the radioactive studies.

Case 2.-A Greek Cypriot woman, aged 22 years, living in London, attended hospital complaining of feeling unduly tired and weak during the past two years. On examination there were no abnormal physical signs apart from slight pallor. Her spleen was not palpable.
The investigations in both cases are set out in the table below.

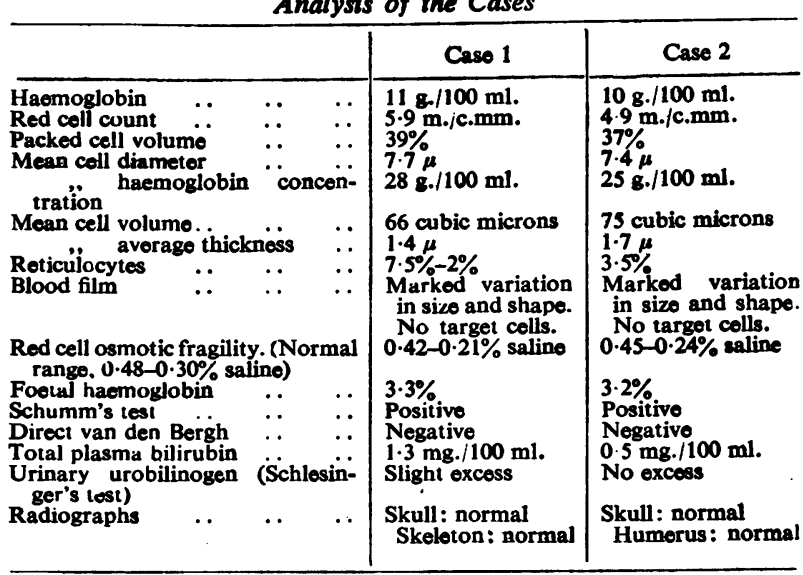

Results of Radioactive Iron and Chromium Studies

Figs. 1 and 2 show the results of these analyses. The uptake of ${ }^{80} \mathrm{Fe}$ was reduced over the marrow sites in the fourth and fifth lumbar vertebrae, but was increased in the shafts of the long bones. These results are interpreted as showing a reduction in marrow activity per unit volume of marrow, but an increase in total marrow volume due to peripheral spread in the skeleton. The reduction in marrow activity was more pronounced in Case 1. In both cases the ${ }^{50} \mathrm{Fe}$ uptake over the spleen and liver showed no evidence of extramedullary red cell production. The rate of ${ }^{89} \mathrm{Fe}$ appearance in the red cells was slightly increased-T $\frac{1}{2} *$ Case $1=3.0$ days, Case 2= 2.7 days (normal $=3.1$ \pm 0.2 days)-indicating a slightly increased output of red cells.

The ${ }^{61} \mathrm{Cr}$ survival time of red cells was slightly reduced in Case $2-\mathrm{T} \frac{1}{2} \dagger=13$ days (normal 22-24 days)-and the mean cell life may be calculated to be about 70 days. There was no evidence of any excessive red cell destruction in the spleen. In Case 1 the ${ }^{31} \mathrm{Cr}$ survival time of the red cells was

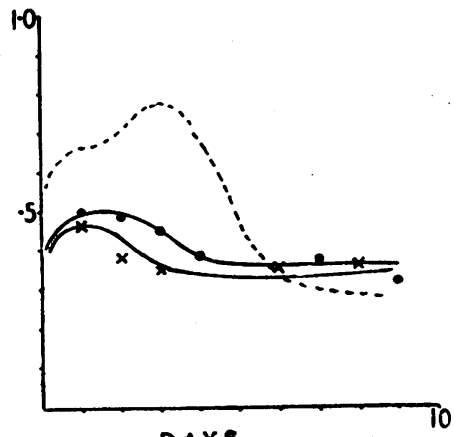

DAYS

Fig. 1.-Uptake of ${ }^{50} \mathrm{Fe}$ measured as relative activity over $L .4$ and 5 . Vertical axis $=$ Relative units of radioactivity. $x-X=$ Case 1 $0=$ Ciso 2 . $\ldots . .-=$ Normal

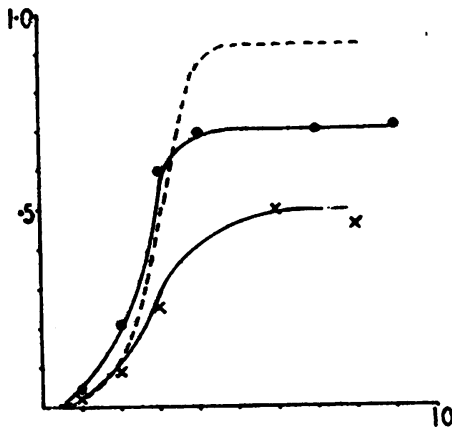

DAYS

Fig. 2.-Rate of appearance of ${ }^{39} \mathrm{Fe}$ in red cells. Vertical axis = Fraction of injected ${ }^{\circ \circ} \mathrm{Fe}$ in red cells. $x \longrightarrow x=$ Case 1 . $=$ Case 2. $\ldots .-.=$ Normal. almost normal-T $+\uparrow=20$ days-but earlier there had been undoubted indirect evidence of haemolysis.

\section{The Family of Case 1}

1. Aged 68. Her blood contained about $10 \%$ of haemoglobin$H$ and she had the clinical and haematological picture of haemoglobin-H disease. Haemoglobin 9 g. $/ 100 \mathrm{ml}$.

2. Deceased.

*Half the time taken for the radioactive iron in the red cells to reach equilibrium

t Half the time taken for the disappearance of radioactive chromium from the peripheral blood. 
3. No abnormality found on clinical and haematological examination. Osmotic fragility of red cells within normal limits. Foetal haemoglobin $2 \%$ of total.

4. No abnormality on clinical and haematological examination. Osmotic fragility of red cells was within normal limits. Foetal haemoglobin less than $2 \%$ of total.

5. Case 1, described.

6 and 7. No haemoglobin-H found on paper electrophoresis. Foetal haemoglobin less than $2 \%$ of total.

Paper electrophoresis did not show any increase of $\mathrm{HbA}_{2}$ in any of the relatives of Case 1.

\section{The Family of Case 2}

1. Paper electrophoresis showed no haemoglobin-H. Haemoglobin $8.9 \mathrm{~g} . / 100 \mathrm{ml}$. This anaemia responded to the administration of iron, her haemoglobin rising to $12 \mathrm{~g} . / 100 \mathrm{ml}$. Foetal haemoglobin $2 \%$ of total.

2. Not examined.

3. Electrophoresis showed haemoglobins $A$ and $H$. She was suffering from a mild anaemia, similar to Case 2 ; haemoglobin $10.4 \mathrm{~g} . / 100 \mathrm{ml}$. Occasional target cells seen in blood film. Foetal haemoglobin less than $2 \%$ of total.

4. Case 2, described.

5. Not examined.

6. Paper electrophoresis showed no haemoglobin-H. Foetal haemoglobin less than $2 \%$ of total.

7. Paper electrophoresis showed no haemoglobin-H. Foetal haemoglobin $5 \%$ of total. (Child aged $1 \frac{1}{2}$ years; haemoglobin $13 \mathrm{~g} . / 100 \mathrm{ml}$.; normal red cell fragility.)

Paper electrophoresis did not show any increase of $\mathrm{HbA}_{2}$ in any of the relatives of Case 2.
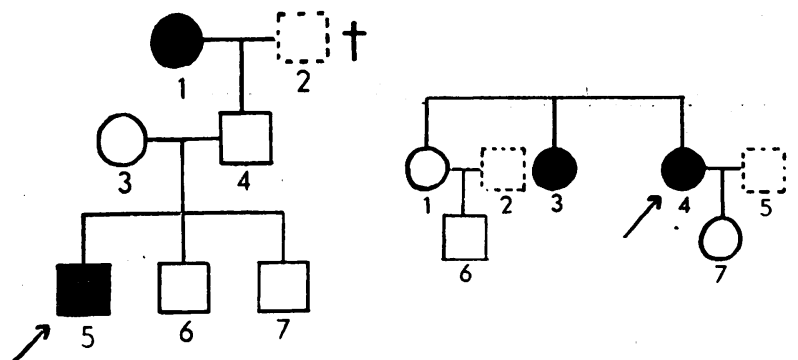

Fra. 3.-Family tree of Case 1.

Fig. 4.-Family tree of Case 2.

Discussion

The results described show that haemoglobin- $\mathrm{H}$ disease is characterized by a slight reduction in the life span of red cells which is not associated with splenic destruction. There is a decrease in marrow activity, which is compensated for by marrow extension, and this results in a slight increase in total red cell output. Output, however, does not compensate completely for haemolysis. The life span of red cells appears to be variable, as a patient who at one time showed clear evidence of haemolysis later had an almost normal cell survival. These findings are similar to those in thalassaemia (Bailey and Prankerd, 1958), which the disease closely resembles in clinical features and haematological findings. However, it differs from thalassaemia minor in that $\mathrm{HbA}_{2}$ is not increased in the patients or their relatives (Vella, Wells, Ager, and Lehmann, 1958). The cases so far reported have been from races in which thalassaemia occurs (Vella et al., 1958); and Motulsky (1956) states that haemoglobin-H disease is the result of the interaction of the thalassaemia and " $H$ " genes. Our two families show no evidence to support this theory, as none of the relatives have thalassaemia.

\section{Summary}

Four cases of haemoglobin-H disease are reported from two Greek Cypriot families living in London. One case from each family has been studied in detail, and results of red cell survival time and marrow iron turnover are presented. The familial nature of the disease is demonstrated.
We are grateful to Dr. E. A. Blake Pritchard for permission to study and publish Case 1 .

\section{REFERENCES}

Bailey, I. S., and Prankerd, T. A. J. (1958). Brit. J. Haemat., 4, 150 Harris, I. M., McAlister, Joan M., Prankerd, T. A. J., and Singh, M. M. (1957). Clin. Sct., 16, 633. Joske, R. A., McAlister, Joan M., and Prankerd, T. A. J. (1956). Ibid., 15. 511 .

Motulsky, A. G. (1956). Nature (Lond.), 178, 1055

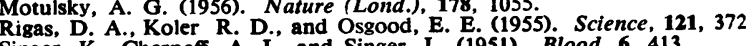

Vella, F., Wells, R. H. C., Ager, J. A. M., and Lehmann, H. (1958). Brtt. med. J., 1.752

\section{TOXIC PSYCHOSIS FOLLOWING ATROPINE EYE-DROPS}

\author{
BY
}

\section{J. P. BAKER, M.B., M.R.C.S.}

AND

J. D. FARLEY, M.B., B.S.

From the Three Counties Hospital, Arlesey, Beds

It is well known that atropine may produce a delirium in addition to its more characteristic autonomic effects. and that in certain sensitive subjects these effects will arise with normal pharmacological doses. It is less well known that atropine can produce delirious states with minor or absent peripheral signs of intoxication and that severe mental reactions can follow routine instillation of atropine eye-drops.

The case described is one of acute toxic psychosis caused by routine atropinization of the right eye over a period of three and a half weeks in the course of treatment of retinal detachment.

The condition is rare in adults and few cases have been reported in the literature (Hopkins and RobynsJones, 1937 ; Listwan and Whealy, 1953 ; Schinko, 1954), but it is suggested that milder degrees of mental disturbance often seen after eye surgery and attributed to emotional stress of the post-operative regime may be due in part to atropine intoxication.

\section{Case Report}

The patient was a married woman of 33, without children intelligent, and described by her family as somewhat highly strung, emotional, and imaginative. After the death of her father two years ago she had spent three days in a neurosis unit, the diagnosis being reactive depression with hysterical features. There was a similar episode 11 years ago after the death of her first husband, but without admission to hospital.

The medical history included rheumatic fever at the age of 12 , followed by a slight persistent tachycardia, and myopia requiring 10 dioptres correction. She had recently worn contact lenses. There was no significant family history.

On June 29, 1957, she was admitted to Moorfields Annexe. Highgate, with a right temporal retinal detachment. Treatment with bed rest, double eye pads, and daily instillations of $1 \%$ atropine sulphate drops was instituted. On July 4 she was transferred to Moorfields Hospital, where the atropine drops were instilled twice daily. At this time she was judged to be "unstable in temperament," and phenobarbitone, $\frac{1}{2}$ gr. ( $32 \mathrm{mg}$.) t.d.s., was added to her treatment.

Diathermy and subretinal aspiration was performed on July 8 under thiopentone, gallamine triethiodide, gas and oxygen, with premedication by "omnopon" and scopolamine. There were no complications. Atropine drops twice daily, eye pads, and strict bed rest were continued until July 19, when masked glasses were substituted for the pads, 